\title{
FORMATION OF TEACHER INNOVATIVE ACTIVITY
}

\author{
Dilshod Akhmatovich Mullaev
}

Doctor Of Philosophy In Biological Sciences (Phd), Associate Professor Of "Biology", Tashkent State Pedagogical University Named After Nizami, Uzbekistan

\section{Gulnoza Ikrom Qizi Gulmatova}

2nd Year Master's Degree In Biology, Tashkent State Pedagogical University Named After Nizami, Uzbekistan

\section{ABSTRACT}

The role of the educator and his responsibilities will determine the importance of the attention paid by society and the public to the work of educating the younger generation. In the process of implementing the "National Program of Personnel Training" in our country, the responsibility of teachers to society in educating and educating the younger generation will continue to grow.

KEYWORDS: - In the current situation, the demands of society on educational institutions are growing day by day, and the task of solving these requirements in practice depends on the teacher.

\section{INTRODUCTION}

A teacher of modern educational institutions performs a number of functions, the teacher is the organizer of the educational process in the classroom. The educator is one of the sources of knowledge for students during the lesson, in extracurricular activities, as well as in extracurricular activities, and many educators act as class leaders and are the organizers of the educational process.

Innovation, expressing the pedagogical process, applies not only to its didactic structure, but also to the socially significant results and mental image of the teacher.

The innovative activity of the teacher implies that it takes place in the dynamics of conflict and mutual enrichment of different views.

The effective implementation of a teacher's innovative activity depends on a number of conditions. It includes the teacher's impartiality in dealing with opposing views, his willingness to teach the recognition of a rational situation in different situations. As a result, the teacher has a comprehensive topic (motive) that provides his knowledge and scientific activity.

Themes (motives) of self-activation, selfcreativity, self-knowledge and creativity play an 
CURRENT RESEARCH JOURNAL OF PEDAGOGICS 2(12): 36-38, December

2021 DOI: https://doi.org/10.37547/pedagogics-crjp-02-12-08

ISSN 2767-3278

(C)2021 Master Journals

Crossref doi) 81 Google

Accepted 10 $10^{\text {th }}$ December, 2021 \& Published $15^{\text {th }}$ December, 2021

important role in the work of a teacher. This allows the teacher to be more creative.

An important condition for innovation is to create a new state of communication.

A new state of communication is the ability of a teacher to create his own position of independence, a new attitude to the world, to pedagogical science, to himself. The teacher is not bound by his or her own point of view, he or she is exposed and refined through the rich forms of pedagogical experience. In such situations, the teacher's way of thinking, mental culture changes, emotional feelings develop.

The next condition is the teacher's readiness for culture and communication.

The innovative activity of the teacher is aimed at changing the reality, identifying its problems and solutions.

Changing the pattern of communication between teacher and student is one of the conditions for innovative activity.

New relationships, as in the tradition, should be free of elements such as coercion and judgment. They should be built in the form of peer cooperation, mutual management, mutual assistance. The most important feature of their relationship is the creative collaboration between teacher and student.

Innovative activity is explained by the following main functions:

- conscious analysis of professional activity;

- critical approach to norms;

- readiness for professional news;

- $\quad$ have a creative approach to the world;

- Realize their potential, integrate their lifestyle and aspirations into their professional activities.

This means that the teacher emerges as the author, developer, researcher, user, and promoter of new pedagogical technologies, theories, and concepts.

In today's society, culture and education, the need for teacher innovation is measured by:

- Socio-economic modernization requires a radical overhaul of the education system, methodology and technology of the educational process. In this context, the innovative activity of the teacher consists in the creation, mastering and use of pedagogical innovations;

- Humanization of educational content requires constant search for new organizational forms and technologies of teaching;

- a change in the nature of the teacher's attitude to the development and implementation of pedagogical innovations.

The analysis of teacher innovation requires the use of certain criteria that determine the effectiveness of innovation. These criteria include novelty, optimality, high efficiency, and the ability to creatively apply innovation in public experimentation.

Innovation reflects the essence of the new, the level of novelty, which is offered as a criterion of pedagogical innovation. Educators distinguish between absolute, limited, absolute, conditional, and subjective levels of innovation, which vary according to the level of popularity and scope of application.

The criterion of acceptance refers to the effort and means expended by the teacher and the student to achieve the result.

Effectiveness refers to certain important positive outcomes in a teacher's work.

Pedagogical innovation should, by its very nature, be the property of mass experimentation. Pedagogy innovation is first introduced into the 
CURRENT RESEARCH JOURNAL OF PEDAGOGICS 2(12): 36-38, December

2021 DOI: https://doi.org/10.37547/pedagogics-crjp-02-12-08

ISSN 2767-3278

(C)2021 Master Journals

Crossref do: 81 Google

Accepted 10 ${ }^{\text {th }}$ December, $2021 \&$ Published 15 th December, 2021

work of individual teachers. At the next stage, after testing and objective assessment, pedagogical innovation is recommended for mass implementation.

\section{REFERENCES}

1. O'zbekiston Respublikasi "Ta'lim to'g'risidagi" qonun va "Kadrlar tayyorlash milliy dasturi" - T.: O'zbekiston, 1997.

2. I.A.Karimov. Yuksak ma'naviyat - yengilmas kuch. -T.: «Ma'naviyat". -T.: 2008.

3. I.A.Karimov. O'zbekiston mustaqillikka erishish ostonasida. -T.: "O'zbekiston". -T.: 2011.

4. 4. O'zbekiston Respublikasi

Prezidentining 12 iyunь 2015 yildagi "Oliy ta'lim muasasalarining rahbar va pedagog kadrlarini kayta tayyorlash va malakasini oshirish tizimini yanada takomillashtirish chora-tadbirlari to'g'risida" gi PF-4732 farmoni.

5. A.A. Abduqodirov, F.A.Astanova, F.A.Abduqirova. "Case-stady" uslubi. Nazariya, amaliyot va tajriba. "Tafakkur qanoti" -2012.

6. Azizxodjaeva N.N. Pedagogik texnologiya va pedagogik maxorat. - T.: Cho'lpon, 2005.

7. G’ofurov A.T., Fayzullaev S.S. «Genetika» Toshkent, «Tafakkur»,2010y.

8. G’ofurov A.T. "Evolyutsion ta'limot" Toshkent "O`qituvchi”, 2009 y.

9. G’ofurov A.T., Fayzullaev S.S. «Genetika va yevolyutsion ta'limot » Toshkent, 2013y

10. Tolipova J.O., Biologiyani o'qitishda pedagogik texnologiyalar. -T. 2011 yil.

11. Tolipova J.O., G'ofurov A.T Biologiya o'qitish metodikasi. -T. 2012 yil.

12. Tolipova J.O., Biologiyani o'qitishda innovatsion texnologiyalar. Pedagogika oliy o'quv yurti O'quvchilari uchun darslik. "Cho'lpon" -T.: 2011 yil.

13. Tolipova J.O., Pedagogik kvalimetriya. O'quv qo'llanma. Toshkent-2016. 